\title{
Next Euroson Schools
}

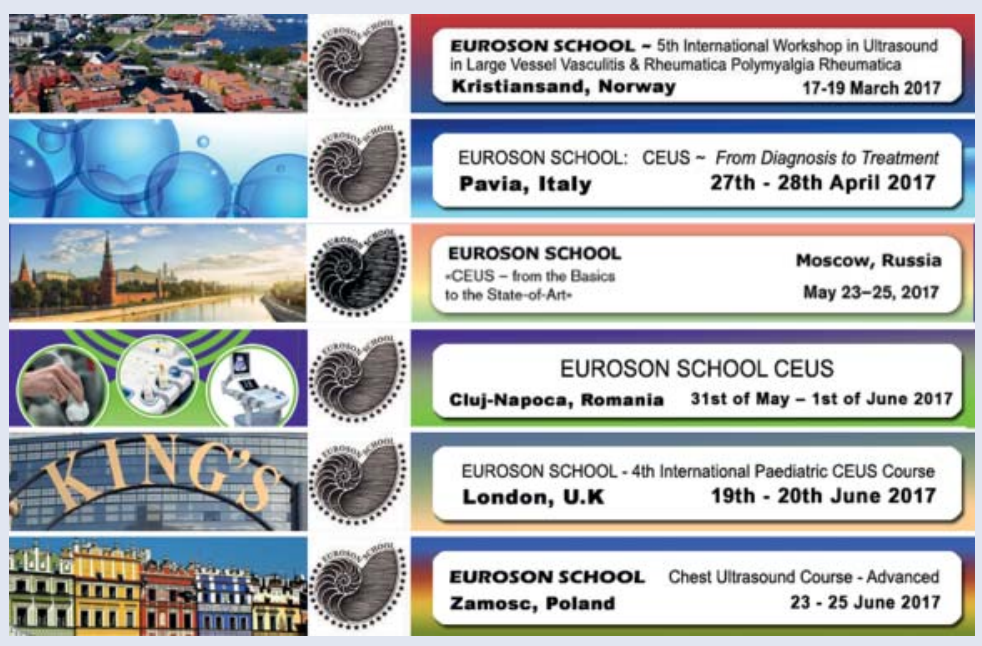

